\title{
JUURNAL.RU
}

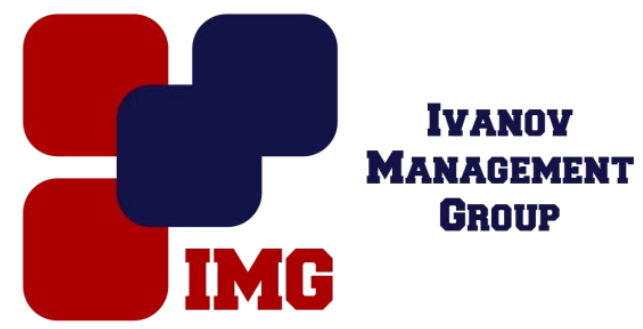

Ильяш Ю.С.

Калужский государственный университет им. К. Э. Циолковского

Калуга, Россия

doi: 10.18411/lj-31-03-2017-1-08

idsp 000001:lj-31-03-2017-1-08

\section{Характеристика персонажей литературной сказки А.Волкова «Волшебник изумрудного города»}

\section{Аннотация}

В данной статье рассматриваются персонажи литературной сказки Волшебник Изумрудного города, их система, характерные черты и поступки.

Ключевые слова: литературная сказка, персонаж, система, характер.

Литературная сказка А.Волкова «Волшебник Изумрудного города» известна читателям не одного поколения. Мы все ее хорошо знаем, неоднократно перечитывали, но никогда не задумывались над тем, какой величайший сакральный смысл она несет.

В сказке фигурирует свыше полутора сотен именованных персонажей, а также значительное количество безымянных действующих лиц. У каждого персонажа своя роль. Персонажи Волкова А.М. многоплановые, разноэмоциональные и разнохарактерные, с присущей им индивидуальностью, поведением и внешностью. Они появляются в произведении постепенно, по ходу раскручивания сюжета, и в зависимости от предназначенной им роли, несут положительные или отрицательные события. В данной статье поговорим об основных, главных персонажах - героев указанного произведения.

Элли - маленькая храбрая девочка, настоящий герой, характер которой проявляется с первых страниц произведения. Она смело бросается спасать своего песика Тотошку, не задумываясь об опасности, грозящей ей самой, а оказавшись в Волшебной стране, смело идет по дороге из желтого кирпича, навстречу опасностям, но с целью исполнить три желания своих новых друзей, для того чтобы вернуться домой.

Тотошку, собаку Элли, Волков А.М. наделяет волшебным свойством умением говорить на человеческом языке. Это сделано не случайно, собачка лучший друг девочки, умный, преданный и бесстрашный песик. Он помогает ей 
во многих сложных ситуациях, и для того, чтобы девочка его понимала, прислушивалась к его советам, песик в Волшебной стране заговорил.

Домик Элли, на котором она прилетела в Волшебную страну, упал на злую волшебницу Гингему и раздавил ее. Тотошка принес Элли башмачки Гингемы, о волшебных свойствах которых она узнает лишь в конце произведения. Добрая волшебница Виллина встречается Элли первой. Она в своей книге, очевидно, увидела способ вернуть Элли домой, но перед этим нужно выполнить три заветных желания своих друзей. И Элли отправляется в путь.

Страшила, встречается на пути девочки первым и сначала кажется глупым и беспомощным, но это только первое и ошибочное впечатление. Он хочет получить мозги, чтобы стать умным. Этот соломенный человечек - на самом деле очень мудрый, рассудительный и храбрый. Ведь именно он предлагает своим друзьям правильные выходы из трудных жизненных ситуаций.

Железный Дровосек - второй из основных главных персонажей и второй желающий исполнения его заветной мечты. Он хочет любить, но для этого ему нужно сердце, которого у него нет. Новый железный друг Элли, Тотошки и Страшилы на самом деле очень чуткий, сердечный и добрый человек.

Трусливый Лев - третий претендент на желание. Он хочет оправдывать свой титул Царя зверей, но он труслив, и он этого очень стыдится. Однако поступки Трусливого Льва говорят об обратном. Он смелый, храбрый, самоотверженный и большой друг для своих маленьких друзей.

Дорога из желтого кирпича полна опасностей, тревог и трудностей, которые подстерегают пятерых путников повсюду. Но герои становятся сильнее. Бурная река, глубокая пропасть, саблезубые тигры, злая волшебница Бастинда, Летучие обезьяны - это испытания, которые обязательно должна преодолеть Элли, чтобы попасть в Изумрудный город.

Осуществление Великим Гудвином их желаний, по сути, только подтверждения всех тех качеств, которыми они хотели обладать, и сами того не осознавая, пронесли их через свои поступки в произведении.

Великий и Ужасный Гудвин появляется в конце произведения. Это мечтатель-неудачник который работал в цирке в штате Канзасс, и которого ураган, так же как и Эли, занес в Зеленую страну. Принятый случайно местными жителями за волшебника, Гудвин стал правителем. Но и здесь удача ему не улыбнулась, так как для строительства Изумрудного города не хватило материала. Так появилась смешная афера с зелеными очками. Но Гудвину стало скучно и тягостно в Волшебной стране.

Анализируя прочитанное произведение и всех персонажей, которые в нем описаны, можно отметить, что положительных в нем больше, чем отрицательных. Герои литературной сказки А.Волкова учат нас тому, что для счастливой жизни совсем неважно, из чего у твоего друга сделаны мозги или сердце. Главное, чтобы он был верным и надежным товарищем, как были для Элли Страшила, Железный Дровосек, Трусливый лев, Тотошка. 
Автор показывает нам, читателям, что самое лучшее, самое дороге на свете - дружба и взаимная выручка. Они помогали Элли и ее друзьям избежать опасностей в Волшебной стране и добиться исполнения всех их заветных желаний.

\section{Литература}

1. Волков А. Волшебник Изумрудного города. М., «Музыка», 1979.

2. Овчинникова Л. В. Русская литературная сказка XX века: История, классификация, поэтика: Учебное пособие. М.: Флинта: Наука, 2003.

3. Померанцева, Э.В. Русская народная сказка / Э.В. Померанцева - М. Изд-во АН СССР, 1963. 